\title{
CLUSTERING ARTIKEL KONSEP ANTRIAN PADA STRUKTUR DATA
}

\author{
Mochmmad Kevin Ferenza \\ 175110024 \\ Universitas Mitra Indonesia, Tehnnik informatika \\ Ferenzak@gmail.com
}

\begin{abstract}
ABSTRAK
Meningkatnya penggunaan internet telah memicu pertumbuhan dan pertukaran informasi menjadi jauh lebihpesat dibandingkan era sebelumnya.Volume berita elektronik berbahasa Indonesia semakin bertambah besardan menyimpan informasi yang berharga di dalamnya.Pengelompokkan berita berbahasa Indonesia merupakansalah satu solusi yang dapat digunakan untuk mempermudah mencerna informasi penting yang ada didalamnya.Clustering dapat digunakan untuk membantu menganalisis berita dengan mengelompokkan secaraotomatis berita yang memiliki kesamaan. Pada text clustering terdapat suatu permasalahan yaitu adanya fitur fitur yang berdimensi tinggi. Diperlukan metode Feature selection untuk mengurangi dimensi fitur ini. Featureselection memiliki kemampuan mengurangi dimensionalitas suatu data sehingga dapat meningkatkanperformansi clustering. Ada beberapa pendekatan sebagai teknik dari implementasi feature selection, salahsatunya adalah filter based feature selection. Pada penelitian ini, dilakukan analisis perbandingan metodefeature selection antara Term contribution dan Document Frequency. Metodemetode feature selection tersebutditerapkan secara filter feature selection. Pada akhir pengujian, dapat dibuktikan bahwa metode Termcontribution lebih baik daripada Document Frequency karena memperhitungkan frekuensi kemunculan termpada suatu dokumen dan jumlah dokumen yang dimiliki term tersebut, sehingga term yang terpilih adalah termyang khas atau bersifat diskriminator. Hal ini dapat meningkatkan performansi clustering dokumen berdasarkanprecision dan entropy.
\end{abstract}

Kata Kunci : clustering, filter feature selection, Term contribution, Document Frequency 


\title{
1. PENDAHULUAN
}

\author{
QUEUE ( ANTRIAN )
}

Struktur data antrean atau queue adalah suatu bentuk khusus dari linear list, dengan operasi penyisipan (insertion) hanya diperbolehkan pada salah satu sisi, yang disebut sisi belakang (REAR), dan operasi penghapusan (deletion) hanya diperbolehkan pada sisi lainnya, yang disebut sisi depan (FRONT), dari list.

Sebagai contoh dapat kita lihat antrean (Q1, Q2,..,QN). Kita notasikan bagian depan dari antrean Q sebagai FRONT(Q) dan bagian belakang sebagai REAR(Q).

Jadi untuk antrean $\mathrm{Q}=[\mathrm{Q} 1, \mathrm{Q} 2, \ldots, \mathrm{QN}]$ :

$\operatorname{FRONT}(\mathrm{Q})=\mathrm{Q} 1$ dan $\operatorname{REAR}(\mathrm{Q})=\mathrm{QN}$

Kita menggunakan notasi NOEL(Q) untuk menyatakan jumlah elemen di dalam antrean Q. NOEL(Q) mempunyai harga integer. Untuk antrean Q $=[Q 1, Q 2, \ldots, Q N]$, maka $\operatorname{NOEL}(\mathrm{Q})=\mathrm{N}$.

Operator penyisipan (insertion) disebut INSERT dan operator penghapusan (deletion) disebut REMOVE.

\section{TINJAUAN PUSTAKA}

\subsection{Struktur Data}

Dalam istilah ilmu komputer, sebuah struktur adalah cara menyimpan, penyusunan dan pengaturan data didalam media penyimpanan komputer sehingga data tersebut digunakan secara efisien. Menurut The Liang Gie, Hal, Peristiwa atauPernyataan lainnya apapun yang mengandung sesuatu tentang pengetahuan untuk dijadikandasar guna penyusunan keterangan, pembuatan kesimpulan/penerapan keputusan.

Data adalah ibaratkan data mentah yang melalui pengolahan tertentu lalu menjadi keterangan atau informasi. Jadi, Struktur data berarti tata letak data yang berisi kolom kolom data baik itu kolom yang tampak oleh pengguna atapun kolom yang hanya digunakan untuk keperluan pemrograman yang tidak tampak oleh pengguna.

\section{STUDI KASUS}

Struktur data sebagai dasar penggembangannya dapat dilihat dalam kehidupan sehari-hari. Contohnya ketika berbelanja di supermarket dan ketika akan membayar belanjaan pada kasir, tentu saja yang di lakukan kasir yaitu kasir akan memasukkan data belanjaan pada komputer kecil di sebelahnya dan selembar struk belanjaan berisi daftar belanjaan, lengkap dengan jumlah harga dan kembaliannya pun keluar dari mesin pencetak. Contoh di atas merupakan contoh struktur data di dalam kehidupan sehari-hari yang di dalamnya tersimpan data semua produk barang, harga barang, dll.

\section{DISKUSI}




\section{Antrian}

A : Saya sering sekali mendengar kata Antrian, apa arti dari Antrian tersebut ?

B : Antrian adalah suatu bentuk khusus dari linear list, dengan operasi penyisipan (insertion) hanya diperbolehkan pada salah satu sisi, yang disebut sisi belakang (REAR), dan operasi penghapusan (deletion) hanya diperbolehkan pada sisi lainnya, yang disebut sisi depan (FRONT), dari list.

$\mathrm{C}$ : Jadi untuk antrean $\mathrm{Q}=[\mathrm{Q} 1, \mathrm{Q} 2, \ldots, \mathrm{QN}]$ :

$\mathrm{FRONT}(\mathrm{Q})=\mathrm{Q} 1$ dan $\operatorname{REAR}(\mathrm{Q})=\mathrm{QN}$

Kita menggunakan notasi NOEL(Q) untuk menyatakan jumlah elemen di dalam antrean Q. NOEL $(\mathrm{Q})$ mempunyai harga integer. Untuk antrean $\mathrm{Q}=[\mathrm{Q} 1, \mathrm{Q} 2, \ldots, \mathrm{QN}]$, maka $\operatorname{NOEL}(\mathrm{Q})=\mathrm{N}$.

Operator penyisipan (insertion) disebut INSERT dan operator penghapusan (deletion) disebut REMOVE.

\section{KESIMPULAN}

Jadi Struktur data sebagai dasar penggembangannya dapat dilihat dalam kehidupan sehari-hari. Contoh di atas merupakan contoh struktur data di dalam kehidupan sehari-hari yang di dalamnya tersimpan data semua produk barang, harga barang, dll.

\section{REFERENSI}

[1] PUTRA, Arie Setya; FEBRIANI, Ochi Marshella. Knowledge Management Online Application in PDAM Lampung Province. In: Prosiding International conference on Information Technology and Business (ICITB). 2018. P. 181-187.

[2] FEBRIANI, Ochi Marshella; PUTRA, Arie Setya. Sistem Informasi Monitoring Inventori Barang Pada Balai Riset Standardisasi Industri Bandar Lampung. Jurnal Informatika, 2014, 13.1: 90-98.

[3] Putra, A. S. (2018, July 9). 2018 Artikel Struktur Data , Audit dan Jaringan Komputer. Retrieved from osf.io/3uq8w.

[4] https://charlostfc.wordpress.com/2011/12/03/konsep-antrian-pada-struktur-data/

[5] http://infodanpengertian.blogspot.com/2016/02/pengertian-struktur-data.html\# 